The most obvious benefit from a follow-up protocol would appear to be the opportunity for the healthcare worker to seek evaluation for chronic liver disease and treatment, if eligible. Studies have shown that alpha-interferon therapy may have a beneficial effect among some patients. ${ }^{12}$ In these studies, however, the patients were highly selected and therapy resulted in sustained improvement in $20 \%$ or fewer of those treated; no clinical, demographic, serum biochemical, serological, or histological features have been identified that reliably predict which patients will respond to treatment and sustain a long-term remission.

In the face of all of these limitations and unknowns, it is difficult to formulate a rational policy for postexposure follow-up for HCV infection. Balanced against these difficulties are the individual workers' concerns about their risk and outcome. A definitive answer to this dilemma may have to await advances in our ability to diagnose, determine infectivity, estimate risks, and provide effective therapy for persons exposed to or infected with $\mathrm{HCV}$. In the absence of either pre- or postexposure prophylaxis against this infection, prevention will continue to depend on measures such as universal precautions and other educational tools that limit the opportunity for exposures to occur in the occupational setting.

\section{REFERENCES}

1. Alter MJ, Gerety RJ, Smallwood L, et al. Sporadic non-A, non-B hepatitis: frequency and epidemiology in an urban United States population. J Infect Dis 1982;145:886-893.

2. Alter MJ. The detection, transmission, and outcome of hepatitis C virus infection. Infect Agents Dis 1993;2:155-166.

3. Polish LB, Tong MJ, Co RL, et al. Risk factors for hepatitis C virus infection among health care personnel in a community hospital. Am J Infect Control 1993;21:196-200.

4. Lanphear BP Linnemann CC, Cannon CG, et al. Hepatitis C virus infection in healthcare workers: risk of exposure and infection. Infect Control Hosp Epidemiol 1994;15:745-750.

5. Mitsui T, Iwano K, Masuko K, et al. Hepatitis $\mathrm{C}$ virus infection in medical personnel after needlestick accident. Hepatology 1992;16:1109-1114.

6. Sartori M, La Terra G, Aglietta M, et al. Transmission of hepatitis C via blood splash into conjunctiva. Scand J Infect Dis 1993;25:270 271.

7. Farci P, Alter MJ, Govindarajan S, et al. Lack of protective immunity against reinfection with hepatitis $\mathrm{C}$ virus. Science 1992;258:135-140.

8. Krawczynski K, Alter MJ, Tankersley DL, et al. Studies on protective efficacy of hepatitis $\mathrm{C}$ immunoglobulins (HCIG) in experimental hepatitis $\mathrm{C}$ virus infection [abstract]. Hepatology 1993;18:110A.

9. Ohto H, Terazawa S, Sasaki N, et al. Transmission of hepatitis C virus from mothers to infants. N Engl J Med 1994;330:744-750.

10. Lin HH, Kao JH, Hsu HY, et al. Possible role of high-titer maternal viremia in perinatal transmission of hepatitis $\mathrm{C}$ virus. $J$ Infect Dis 1994:169:638-641.

11. Centers for Disease Control. Public Health Service inter-agency guidelines for screening donors of blood, plasma, organs, tissues, and semen for evidence of hepatitis B and hepatitis C. MMWR 1991;40(RR-4):13-14.

12. Di Bisceglie AM, Hoofnagle JH. Therapy of chronic hepatitis C with alpha-interferon: the answer? or more questions? Hepatology 1991;13:601-603.

\title{
CDC Releases Draft Guideline for Isolation Precautions in Hospitals
}

\section{by Gina Pugliese, RN, MS Medical News Editor}

The CDC has released the Draft Guideline for Isolation Precautions in Hospitals that will replace the 1983 edition, The draft guideline was pub lished in the November 7, 1994, issue of the Federal Register [vol. $59(214): 55552-70]$. The draft guideline was prepared by the USPHS Hospital Infection Control Practices Advisory Committee (HICPAC) and the CDC. The revised guideline contains to tiers of precautions. The first tier is standard precautions designed for the care of all patients; it combines the major features of universal precautions and body substance isolation. The second tier is precautions for patients known or suspected to be infected or colonized with epidemiologically important organisms, including airborne, droplet, and contact precautions. The CDC has suggested that healthcare facilities may wish to consider waiting until the final guidelines are completed in the fall of 1995 before changing current procedures.

Comments on this draft should be submitted in writing by January 6 , 1995, to CDC, Attention: Isolation
Guideline Information Center, Mailstop A-07,1600 Clifton Rd. NE, Atlanta, GA 30333.

The guideline can be viewed and photocopied from the Federal Register at any U.S. Government Repository Library or any library that receives the Federal Register. For the government library nearest you, call (202) 5121800.

Copies of the draft guideline also are available from the American Hospital Association, by calling (800) 242-2626 (catalog no. 0094600; price $\$ 7.95$; includes shipping and handling). 